\title{
An Extract of Antrodia camphorata Mycelia Attenuates the Progression of Nephritis in Systemic Lupus Erythematosus-Prone NZB/W F1 Mice
}

\author{
Jia-Ming Chang, ${ }^{1}$ Yi-Ru Lee, ${ }^{2}$ Le-Mei Hung, ${ }^{1}$ Sheng-Yung Liu, ${ }^{3}$ Mao-Tien Kuo, ${ }^{3}$ \\ Wu-Che Wen, ${ }^{3}$ and Peini Chen ${ }^{4}$ \\ ${ }^{1}$ Division of Research and Development, Development Center for Biotechnology, Xizhi City, Taipei County, Taiwan 221, Taiwan \\ ${ }^{2}$ Institute of Molecular Biology and Biochemistry, College of Medicine, National Taiwan University, Taiwan 111, Taiwan \\ ${ }^{3}$ Golden Biotechnology Corp., Danshuei Township, Taipei County, Taiwan 251, Taiwan \\ ${ }^{4}$ Department of Radiology, Taipei Veterans General Hospital, Taipei, Taiwan 112, Taiwan
}

Correspondence should be addressed to Jia-Ming Chang, jiaming@ntu.edu.tw

Received 4 February 2008; Accepted 7 August 2008

Copyright ( 2011 Jia-Ming Chang et al. This is an open access article distributed under the Creative Commons Attribution License, which permits unrestricted use, distribution, and reproduction in any medium, provided the original work is properly cited.

\begin{abstract}
Antrodia camphorata is used in folk medicine for the treatment of inflammation syndromes and liver-related diseases in Taiwan. The goal of this study was to evaluate the efficacy of the mycelial extract of A. camphorata (ACE) for the treatment of systemic lupus erythematosus (SLE) in SLE-prone NZB/W F1 mice. After antibodies against double-stranded DNA appeared in NZB/W mice, the mice were orally administered varying dosages of ACE (100, 200 and $\left.400 \mathrm{mg} \mathrm{kg}^{-1}\right)$ for 5 consecutive days per week for 12 weeks via gavage. To assess the efficacy of ACE, we measured SLE-associated biochemical and histopathological biomarkers levels of blood urine nitrogen (BUN), blood creatinine, urine protein and urine creatinine and thickness of the kidney glomerular basement membrane by staining with periodic acid-Schiff. Antroquinonol, an active component of ACE, was investigated for antiinflammation activity in lipopolysaccharide-induced RAW 267.4 cells. ACE at $400 \mathrm{mg} \mathrm{kg}^{-1}$ significantly suppressed urine protein and serum BUN levels and decreased the thickness of the kidney glomerular basement membrane. Antroquinonol significantly inhibited the production of tumor necrosis factor- $\alpha$ and interleukin- $1 \beta$ by 75 and $78 \%$, respectively. In conclusion, ACE reduced urine protein and creatinine levels and suppressed the thickening of the kidney glomerular basement membrane, suggesting that ACE protects the kidney from immunological damage resulting from autoimmune disease.
\end{abstract}

\section{Introduction}

Systemic lupus erythematosus (SLE) is an autoimmune disease for which the pathogenesis remains unclear [1]. Patients with SLE produce numerous antibodies against selfantigens in several organs, such as skin, joints and kidneys [2]. The clinical features include fever, photosensitivity, serositis [3] and renal disease, the latter being the most life threatening due to potential development of irreversible kidney failure [4].

It has been suggested that in SLE hyperactive B cells produce auto-antibodies against DNA fragments. These antibodies can then attack the nuclear antigens of organs or form immunocomplex precipitates that affect microcirculation, resulting in organ dysfunction [2]. When precipitated immunocomplexes in the kidney result in glomerulitis, patients will present with significant amounts of protein in the urine. Furthermore, the thickness of glomerular basement membranes is increased in glomerulitis and results in the reduction of blood creatinine clearance, which serves as an important diagnostic parameter for lupus nephritis [5].

The BXSB, MRL/lpr and NZB/W F1 mouse models have been commonly used to validate drug regimens for the treatment of SLE. Male BXSB mice characteristically develop SLE faster than females, which is opposite of that observed in humans [6]. MRL/lpr mice are characterized by lymphadenosis, splenomegaly and polyarthritis. In NZB/W F1 mice, females spontaneously produce auto-antibodies at 5-6 months of age and the mice die from kidney failure. Among these mouse models, the symptoms of SLE-prone 
TABLE 1: Analysis of SLE indicators among SLE-prone NZB/W F1 mice.

\begin{tabular}{lcccc}
\hline Treatment (dose) & $\begin{array}{c}\text { Body weight } \\
(\mathrm{g})^{(\mathrm{a})}\end{array}$ & $\begin{array}{c}\text { Anti-dsDNA IgG } \\
\left(\mathrm{mg} \mathrm{dL}^{-1}\right)^{(\mathrm{a})}\end{array}$ & $\begin{array}{c}\text { Urine protein } \\
\left(\mathrm{mg} \mathrm{dL}^{-1}\right)^{(\mathrm{a})}\end{array}$ & $\begin{array}{c}\text { Urine creatinine } \\
\left(\mathrm{mg} \mathrm{dL}^{-1}\right)^{(\mathrm{a})}\end{array}$ \\
\hline Control-ddH ${ }_{2} \mathrm{O}\left(10 \mathrm{~mL} \mathrm{~kg}^{-1}\right)$ & $35.4 \pm 3.5$ & $3.56 \pm 2.79$ & $89.2 \pm 23.7$ & $39.8 \pm 12.5$ \\
Prednisolone $\left(1.25 \mathrm{mg} \mathrm{kg}^{-1}\right)$ & $34.4 \pm 3.9$ & $4.07 \pm 4.14$ & $88.2 \pm 14.6$ & $38.0 \pm 7.0$ \\
ACE $\left(100 \mathrm{mg} \mathrm{kg}^{-1}\right)$ & $35.4 \pm 3.6$ & $4.86 \pm 7.88$ & $88.6 \pm 16.7$ & $33.7 \pm 10.1$ \\
ACE $\left(200 \mathrm{mg} \mathrm{kg}^{-1}\right)$ & $36.8 \pm 2.8$ & $5.06 \pm 7.87$ & $83.3 \pm 20.2$ & $34.6 \pm 9.5$ \\
ACE $\left(400 \mathrm{mg} \mathrm{kg}^{-1}\right)$ & $35.6 \pm 4.6$ & $5.29 \pm 8.57$ & $90.6 \pm 19.8$ & $40.6 \pm 10.8$ \\
Normal $(\mathrm{C} 57 \mathrm{BL} / 6 \mathrm{j}$ mice $)$ & $18.2 \pm 1.0$ & $1.73 \pm 0.53$ & $75.1 \pm 36.0$ & $33.7 \pm 15.7$ \\
\hline
\end{tabular}

${ }^{(a)}$ Data are expressed as mean $\pm \mathrm{SD}$.

NZB/W F1 mice are most similar to those of human SLE patients $[7,8]$ and therefore provide the most promising model for evaluation of anti-SLE drug activity.

Antrodia camphorata (Polyporaceae, Aphyllophorales), a parasitic fungus on rotting trees of Cinnamomum kanehirai Hay [9], is used in Taiwanese folk medicine for the treatment of diarrhea, abdominal pain, hypertension, itching of the skin and liver cancer. To date, A. camphorata has been cultured as mycelium and has been shown to exhibit certain anti-inflammation $[10,11]$, vasorelaxation [12] and antitumor cytotoxicity $[13,14]$ activities. However, the ability of A. camphorata to inhibit auto-immune diseases has not been subjected to scientific scrutiny.

To assess the anti-SLE efficacy of $A$. camphorata mycelia, we treated SLE-prone NZB/W F1 mice with extracts of a camphorata mycelia and measured the diagnostic parameters associated with lupus nephritis. Furthermore, RAW 264.7 cells, a mouse leukemic monocyte macrophage cell line, were treated with the active ingredient of the extract, antroquinonol, to evaluate its anti-inflammation activity.

\section{Methods}

2.1. Cells and Chemicals. RAW 264.7 cells (TIB-71) were obtained from the American Type Culture Collection (Manassas, VA, USA). ACE and antroquinonol were provided by Golden Biotechnology Co. (Taiwan). Prednisolone was used as a positive control and was purchased from Chin Teng Pharmacy Industrial Co. (Taiwan). Lipopolysaccharide (LPS) was purchased from Sigma Co. (USA). All drugs were stored at $-20^{\circ} \mathrm{C}$ and thawed at $37^{\circ} \mathrm{C}$ before use.

2.2. Animals. Fifty NZB/W F1 female mice were purchased from Jackson Laboratory (Bar Harbor, ME, USA) and mice were maintained under climate-controlled conditions and a 12 hours light-dark cycle. The animals were fed standard rodent chow (PMI Nutrition International, USA). Ten C57BL/6j female mice were purchased from the Animal Center of the National Taiwan University and were used as reference controls. All mice received human care and the study protocol followed the guidelines of the Institutional Animal Care and Use Committees of the Development Center for Biotechnology (accredited by AAALAC).
2.3. Preparation of ACE. The A. camphorata used in this study was authenticated by Dr Tzean Shang-Shong, Department of Plant Pathology and Microbiology, National Taiwan University, Taiwan. The mycelium of A. camphorata was cultured in $1000 \mathrm{~mL}$ growth medium containing $0.1 \mathrm{~g} \mathrm{NaCl}$, $10 \mathrm{~g}$ peptone, $2 \mathrm{~g}$ yeast extract, $10 \mathrm{~g}$ agar and $10 \mathrm{~g}$ cereal mixture (rice, wheat or corn), $\mathrm{pH} 7.5$ at $25^{\circ} \mathrm{C}$ for $12-14$ weeks. After cultivation, $500 \mathrm{~g}$ of lyophilized A. camphorata mycelium was extracted with $2500 \mathrm{~mL} n$-hexane for 6 hours. The $n$-hexane fraction, defined as ACE (GD-66, product name and GD-AIDT7, batch name), was concentrated to 20$30 \mathrm{~mL}$ via vacuum evaporation and the antroquinonol was purified from ACE by silica gel chromatography (column $=45 \mathrm{~cm}, 5 \mathrm{~cm}$ i.d.) (ASTM silica gel, Merck Co., Germany) and eluted with $n$-hexane:ethyl acetate $(10: 3 \mathrm{v} / \mathrm{v})$. The resulting eluate was further subjected to size exclusion chromatography using Sephadex LH20 column $(70 \mathrm{~cm}$ long, $5 \mathrm{~cm}$ i.d.) (AB gel, GE Healthcare Bio-Science, USA). The antroquinonol (98\% purity) was eluted with $95 \%$ ethanol as described in the study of Lee et al. [9]; the ACE fraction was determined to have $0.01 \%$ antroquinonol.

2.4. Drug Treatment. After NZB/W F1 mice were 23 weeks old, blood was collected for determination of IgG against double-stranded DNA (anti-dsDNA). Mice positive for antidsDNA IgG were divided into five groups of 10 mice each and treated with various concentrations of ACE or prednisolone by gavage for 5 consecutive days per week for 12 weeks as follows: (i) disease group, $\mathrm{ddH}_{2} \mathrm{O}$ treatment $\left(10 \mathrm{~mL} \mathrm{~kg}^{-1}\right)$, (ii) positive control group, prednisolone treatment (1.25 mg kg-1), (iii) ACE treatment $\left(100 \mathrm{mg} \mathrm{kg}^{-1}\right.$ ), (iv) ACE treatment $\left(200 \mathrm{mg} \mathrm{kg}^{-1}\right)$ and (v) ACE treatment (400 $\mathrm{mg} \mathrm{kg}^{-1}$ ) (Table 1). Ten C57BL/6j mice were used as reference group in this experiment.

2.5. Analysis of Blood Urea Nitrogen and Urine Protein. For analysis of blood urea nitrogen (BUN), serum samples were thawed at room temperature and then loaded on a BUN diagnostic kit slide. BUN was measured using an automated analyzer (BUN_Vitros DT6011, Johnson-Johnson, USA). For analysis of urine protein, urine was collected by pressing the bladder of mice with fingertips every 2 weeks. Urine protein was determined using the Bio-Rad Protein Assay 
TABLE 2: Body weight change in NZB/W F1 mice with treatment time ${ }^{(a)}$.

\begin{tabular}{|c|c|c|c|c|c|c|c|}
\hline Treatment (dose) & Week $0^{(b),(c)}$ & Week $2^{(b),(c)}$ & Week $4^{(\mathrm{b}),(\mathrm{c})}$ & Week $6^{(\mathrm{b}),(\mathrm{c})}$ & Week $8^{(\mathrm{b}),(\mathrm{c})}$ & Week $10^{(\mathrm{b}),(\mathrm{c})}$ & Week $12^{(\mathrm{b}),(\mathrm{c})}$ \\
\hline $\begin{array}{l}\text { Control- } \mathrm{ddH}_{2} \mathrm{O} \\
\quad\left(10 \mathrm{~mL} \mathrm{~kg}^{-1}\right)\end{array}$ & $\begin{array}{l}35.4 \pm 3.5 \\
(0 \%)\end{array}$ & $\begin{array}{l}36.4 \pm 4.0 \\
(2.8 \%)\end{array}$ & $\begin{array}{l}37.4 \pm 3.2 \\
(5.6 \%)\end{array}$ & $\begin{array}{l}38.3 \pm 3.9 \\
(8.2 \%)\end{array}$ & $\begin{array}{l}38.9 \pm 4.1 \\
(9.9 \%)\end{array}$ & $\begin{array}{l}37.6 \pm 3.6 \\
(6.2 \%)\end{array}$ & $\begin{array}{l}35.8 \pm 4.9 \\
(1.1 \%)\end{array}$ \\
\hline $\begin{array}{l}\text { Prednisolone } \\
\qquad\left(1.25 \mathrm{mg} \mathrm{kg}^{-1}\right)\end{array}$ & $\begin{array}{l}34.4 \pm 3.9 \\
(0 \%)\end{array}$ & $\begin{array}{l}34.0 \pm 3.9 \\
(-1.2 \%)\end{array}$ & $\begin{array}{l}36.1 \pm 4.0 \\
(4.9 \%)\end{array}$ & $\begin{array}{l}36.2 \pm 4.2 \\
(5.2 \%)\end{array}$ & $\begin{array}{l}37.6 \pm 3.5 \\
(9.3 \%)\end{array}$ & $\begin{array}{l}36.1 \pm 3.3 \\
(4.9 \%)\end{array}$ & $\begin{array}{l}36.3 \pm 3.4 \\
(5.5 \%)\end{array}$ \\
\hline $\begin{array}{l}\text { ACE } \\
\qquad\left(100 \mathrm{mg} \mathrm{kg}^{-1}\right)\end{array}$ & $\begin{array}{l}35.4 \pm 3.6 \\
(0 \%)\end{array}$ & $\begin{array}{l}35.2 \pm 3.3 \\
(-0.6 \%)\end{array}$ & $\begin{array}{l}36.7 \pm 3.2 \\
(3.7 \%)\end{array}$ & $\begin{array}{l}36.7 \pm 4.2 \\
(3.7 \%)\end{array}$ & $\begin{array}{l}37.1 \pm 5.7 \\
(4.8 \%)\end{array}$ & $\begin{array}{l}37.8 \pm 1.8 \\
(6.8 \%)\end{array}$ & $\begin{array}{l}36.5 \pm 3.1 \\
(3.1 \%)\end{array}$ \\
\hline $\begin{array}{l}\text { ACE } \\
\qquad\left(200 \mathrm{mg} \mathrm{kg}^{-1}\right)\end{array}$ & $\begin{array}{l}36.8 \pm 2.8 \\
(0 \%)\end{array}$ & $\begin{array}{l}37.4 \pm 2.6 \\
(1.6 \%)\end{array}$ & $\begin{array}{l}37.5 \pm 3.0 \\
(1.9 \%)\end{array}$ & $\begin{array}{l}38.3 \pm 3.6 \\
(4.1 \%)\end{array}$ & $\begin{array}{l}38.7 \pm 4.9 \\
(5.2 \%)\end{array}$ & $\begin{array}{l}38.9 \pm 2.1 \\
(5.7 \%)\end{array}$ & $\begin{array}{l}39.0 \pm 2.0 \\
(6.0 \%)\end{array}$ \\
\hline $\begin{array}{l}\text { ACE } \\
\qquad\left(400 \mathrm{mg} \mathrm{kg}^{-1}\right)\end{array}$ & $\begin{array}{l}35.6 \pm 4.6 \\
(0 \%)\end{array}$ & $\begin{array}{l}35.5 \pm 4.5 \\
(0 \%)\end{array}$ & $\begin{array}{l}36.7 \pm 4.5 \\
(3.1 \%)\end{array}$ & $\begin{array}{l}36.8 \pm 5.0 \\
(3.4 \%)\end{array}$ & $\begin{array}{l}37.2 \pm 6.1 \\
(4.5 \%)\end{array}$ & $\begin{array}{l}37.0 \pm 8.2 \\
(3.9 \%)\end{array}$ & $\begin{array}{l}37.9 \pm 6.3 \\
(6.5 \%)\end{array}$ \\
\hline
\end{tabular}

(a) Fifty NZB/W F1 female mice were divided into 5 groups of 10 each. Different doses of ACE and prednisolone were administrated by gavages for 5 consecutive days per week for 12 weeks.

(b) Data are expressed as mean $\pm \mathrm{SD}$.

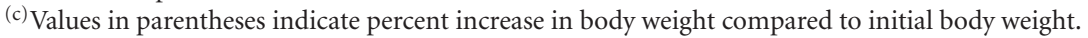

Dye Reagent Concentrate according to the manufacturer's instructions, using bovine serum albumin as the standard. Optical density (OD) was measured at $595 \mathrm{~nm}$.

2.6. Analysis of Serum and Urine Creatinine. Creatinine was determined by a Creatinine (Direct) Reagent Set (Eagle Diagnostics), according to the manufacturer's instruction. The urine samples were diluted with deionized water $(1: 10)$ and mixed with an equal volume of the diluted reagent provided in the kit in a 96-well microtiter plate and incubated for $15 \mathrm{~min}$ at room temperature. The $\mathrm{OD}$ at $510 \mathrm{~nm}$ was then determined and the concentration of urine creatinine was calculated as follows: creatinine $\left(\mathrm{mg} \mathrm{dL}^{-1}\right)=[$ (sample ODblank OD) $\times 6 \mathrm{mg} \mathrm{dL}^{-1} /($ sample OD-blank OD)]. Serum creatinine was measured using the urine creatinine protocol but no dilution was needed for measuring serum creatinine.

2.7. Determination of Serum Anti-dsDNA IgG. The levels of anti-dsDNA IgG were determined using a mouse antidsDNA IgG ELISA kit (Alpha Diagnostic, USA), according to the manufacturer's instructions. In brief, blood serum samples were diluted 100-fold with buffer (provided by the kit) and added to a 96-well ELISA plate and incubated for 2 hours at room temperature. Samples were then washed thrice with washing buffer (provided by the kit) and horseradish peroxidase-conjugated anti-IgG antibodies were then added and incubated for 1 hour at room temperature. The samples were washed five times with washing buffer and horseradish peroxidase substrate solution was added and incubated for $15 \mathrm{~min}$ at room temperature. The $\mathrm{OD}$ was measured at $450 \mathrm{~nm}$ using an ELISA reader. (Multiskan EX, Thermo Scientific Co., USA). The concentration of the anti-dsDNA was calculated using a bovine serum albumin standard calibration curve.

2.8. Histopathological Examination. After sacrificing the animals, the kidneys were collected. A pathological examination was performed and sections were paraffin fixed and stained by haematoxylin and eosin and periodic acid-Schiff (PAS). PAS was used to stain the kidney glomerular basement membrane.

2.9. Anti-Inflammation Assay. RAW 264.7 cells were seeded onto a 24-well plate at a density of $5 \times 10^{5}$ cells/well and incubated at $37^{\circ} \mathrm{C}$ for 24 hours under $5 \% \mathrm{CO}_{2}$. RAW 264.7 cells were treated with varying concentrations of antroquinonol (MW 391) $(0.256,2.56,25.6$ and $256 \mu \mathrm{M})$ for 24 hours in the presence of $1 \mu \mathrm{g} \mathrm{mL}^{-1}$ LPS. After treatment, the medium was analyzed by ELISA to determine the secretion of tumor necrosis factor- $\alpha$ (TNF- $\alpha$ ) and interleukin (IL)- $1 \beta$ cytokines, as described in the study of Chang et al. [15].

2.10. Statistical Analysis. Statistical analysis of in vivo data was performed using one-way ANOVA (SPSS software package). In vitro data were analyzed using the Student's $t$-test. Differences in values were considered significant at $P<.05$.

\section{Results}

3.1. Decreased Serum BUN Levels in ACE-Treated NZB/W Mice. Fifty NZB/W F1 female mice were divided into 5 groups of 10 mice each. Varying doses of ACE and prednisolone were administrated by gavage 5 consecutive days/week for 12 weeks. The body weight of NZB/W F1 mice was recorded every 2 weeks (Table 2). The growth of NZB/W F1 mice was not affected in the ACE- and prednisolonetreated groups, whereas the growth was significantly inhibited (only a $1.1 \%$ increase in body weight compared to initial body weight) in vehicle-treated NZB/W F1 mice at the end of the 12 week experiment. Mice displayed an increase in body weight of 3.1, 6.0 and $6.5 \%$, when treated with 100,200 and $400 \mathrm{mg} \mathrm{kg}^{-1}$ doses of ACE, respectively. The increase in body weight reflected the improved condition of SLE mice, suggesting that ACE might improve the cachexia symptoms of SLE disease. 


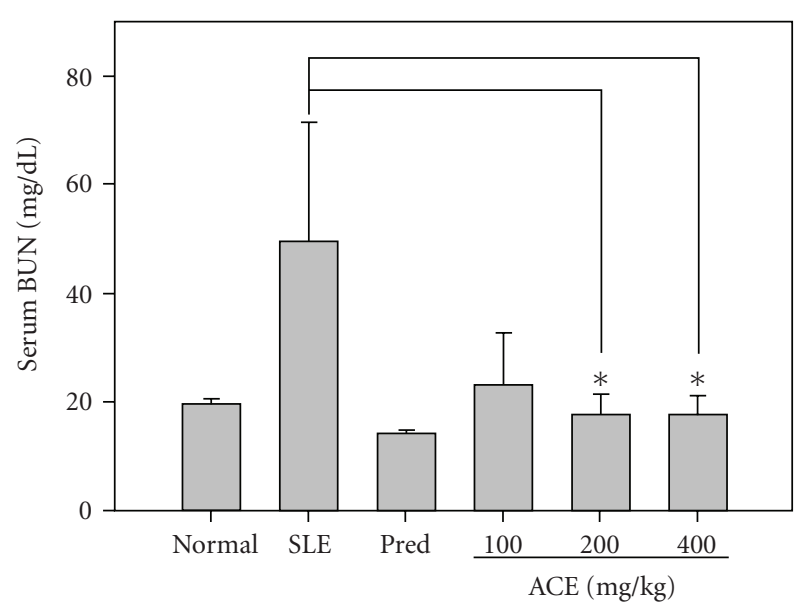

(a)

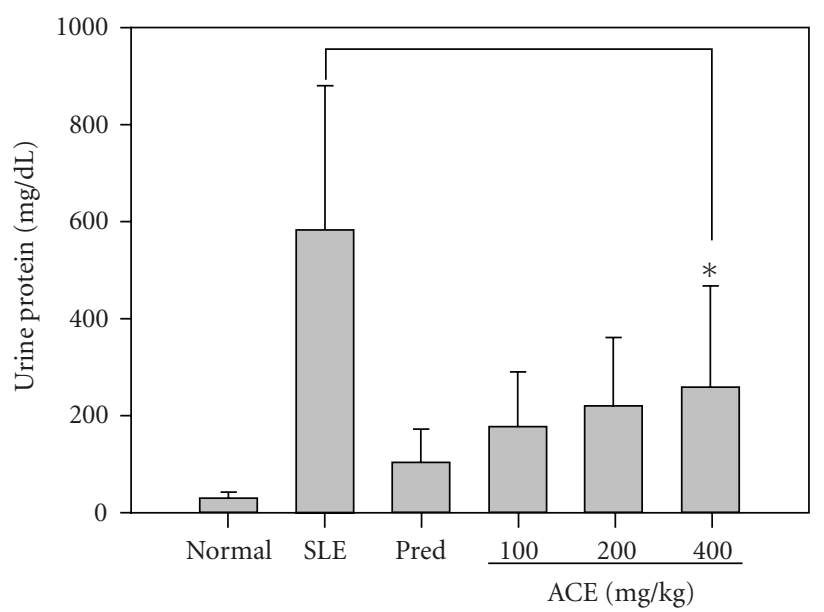

(c)

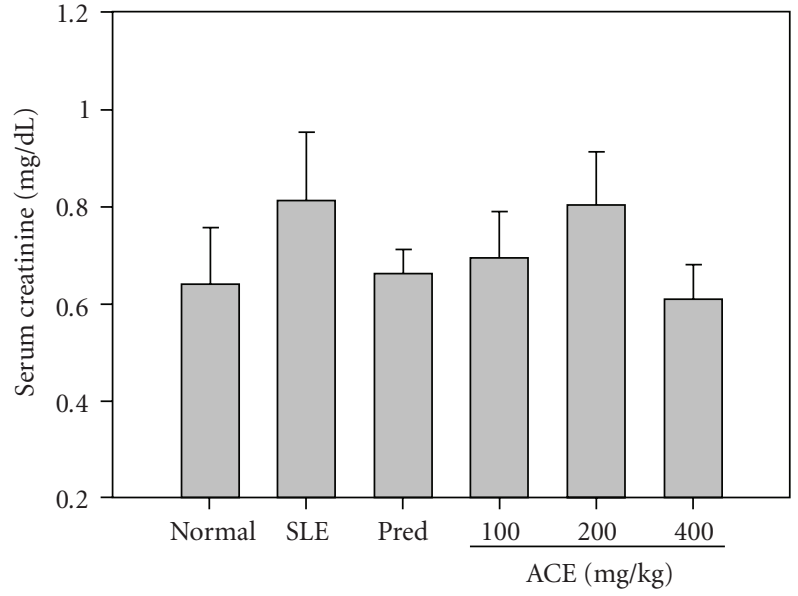

(b)

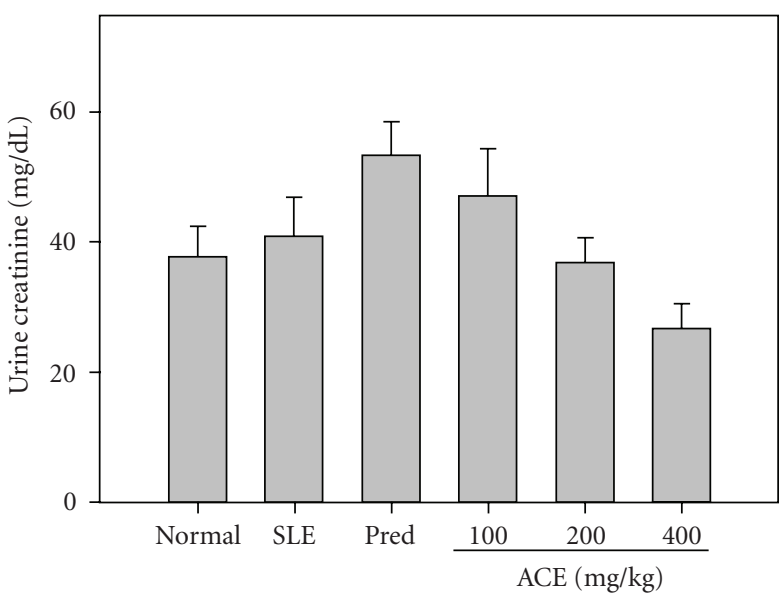

(d)

Figure 1: ACE maintains kidney function in SLE-prone mice. The NZB/W F1 mice were treated with different dosages of ACE (100, 200 and $400 \mathrm{mg} \mathrm{kg}^{-1}$ ) and prednisolone $\left(1.25 \mathrm{mg} \mathrm{kg}^{-1}\right)$ consecutively for 5 days per week for 12 weeks. At the end of experiment, blood of experimental animals was collected and serum was determined for the concentration of (a) serum BUN and (b) serum creatinine. Before the sacrifice of animals, urine was collected and then (c) urine protein and (d) urine creatinine were determined as described in Methods section.

To evaluate whether kidney function in SLE-prone $\mathrm{NZB} / \mathrm{W}$ F1 mice was protected by ACE, serum creatinine and BUN levels were analyzed following the 12 week ACE treatment regimen. As shown in Figure 1(a), BUN levels were elevated to $49.5 \pm 1.0 \mathrm{mg} \mathrm{dL}^{-1}$ in vehicle-treated $\mathrm{NZB} / \mathrm{W}$ F1 mice, whereas BUN levels were decreased to $14.2 \pm$ $0.6 \mathrm{mg} \mathrm{dL}^{-1}$ in prednisolone-treated mice. Likewise, BUN levels were decreased among mice treated with different doses of ACE $\left(23.0 \pm 9.7 \mathrm{mg} \mathrm{dL}^{-1}\right.$ for $100 \mathrm{mg} \mathrm{kg}^{-1} \mathrm{ACE}$ group, $17.8 \pm 3.5 \mathrm{mg} \mathrm{dL}^{-1}$ for $200 \mathrm{mg} \mathrm{kg}^{-1} \mathrm{ACE}$ group and $17.8 \pm 3.3 \mathrm{mg} \mathrm{dL}^{-1}$ for $400 \mathrm{mg} \mathrm{kg}^{-1}$ ACE group). Thus, at dosages of 200 and $400 \mathrm{mg} \mathrm{kg}^{-1}$, ACE treatment decreased BUN levels by $64 \%$. Furthermore, lower creatinine levels were observed in the prednisolone group $\left(0.67 \mathrm{mg} \mathrm{dL}^{-1}\right)$ and ACE groups $\left(0.69 \mathrm{mg} \mathrm{dL}^{-1}\right.$ in $100 \mathrm{mg} \mathrm{kg}^{-1}$ treatment group and $0.62 \mathrm{mg} \mathrm{dL}^{-1}$ in $400 \mathrm{mg} \mathrm{kg}^{-1}$ treatment group) com- pared to SLE-disease group $\left(0.81 \mathrm{mg} \mathrm{dL}^{-1}\right)$ (Figure $1(\mathrm{~b})$ ). Furthermore, prednisolone treatment decreased serum creatinine levels to $0.67 \pm 0.05 \mathrm{mg} \mathrm{dL}^{-1}$ in NZB/W F1 mice as did ACE treatment (serum creatinine $=0.69 \pm 0.10 \mathrm{mg} \mathrm{dL}^{-1}$ in the $100 \mathrm{mg} \mathrm{kg}^{-1} \mathrm{ACE}$ treatment group and $0.62 \pm$ $0.07 \mathrm{mg} \mathrm{dL}^{-1}$ in the $400 \mathrm{mg} \mathrm{kg}^{-1}$ ACE treatment group) compared to SLE-disease group of NZB/W F1 mice (serum creatinine $\left.=0.81 \pm 0.14 \mathrm{mg} \mathrm{dL}^{-1}\right)$. These results suggested that kidney function, including serum creatinine clearance, is maintained by ACE treatment.

3.2. Attenuation of Nephritis in SLE-Prone NZB/W F1 Mice. To evaluate the severity of nephritis in ACE-treated $\mathrm{NZB} / \mathrm{W}$ F1 mice, urine protein and creatinine were analyzed, which are indicators of severity for lupus nephritis. The concentration of urine protein in the SLE disease group 


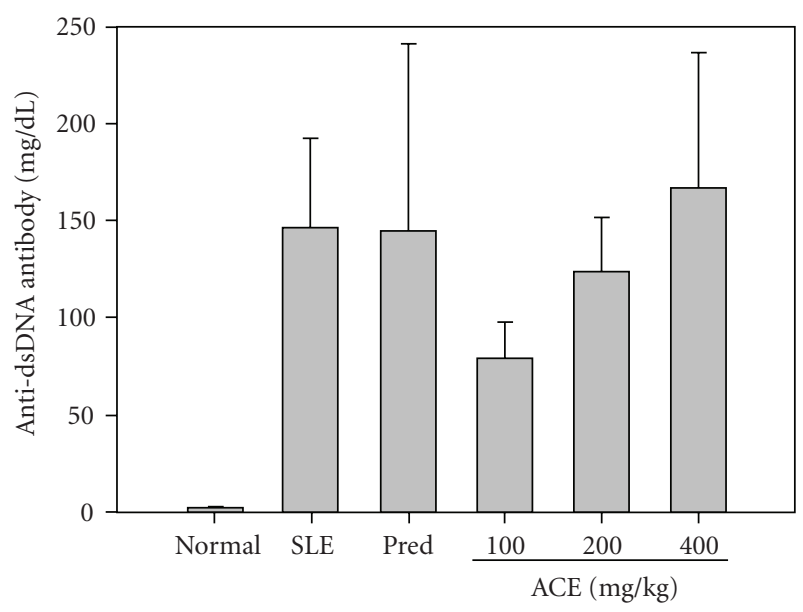

Figure 2: ACE inhibits immunological kidney damage in SLEprone mice. The NZB/W F1 mice were treated with different dosages of $\mathrm{ACE}\left(100,200\right.$ and $\left.400 \mathrm{mg} \mathrm{kg}^{-1}\right)$ and prednisolone $\left(1.25 \mathrm{mg} \mathrm{kg}^{-1}\right)$ consecutively for 5 days per week for 12 weeks. At the end of experiment, blood of experimental animals was collected and serum was tested for anti-dsDNA IgG using a mouse anti-ds DNA IgG ELISA kit.

was dramatically increased to $581.8 \pm 298.7 \mathrm{mg} \mathrm{dL}^{-1}$ at the end of the 12 week experiment, which was consistent with the body weight loss and indicated the onset of nephritis (Figure 1(c)). Prednisolone inhibited the increase in the levels of urine protein by $82 \%$ and 100, 200 and $400 \mathrm{mg} \mathrm{kg}^{-1}$ per dose of ACE inhibited urine protein by 69, 62 and $55 \%$, respectively. As shown in Figure 1(d), the levels of urine creatinine were normal in the SLE-disease group (40.9 $\left.\pm 0.6 \mathrm{mg} \mathrm{dL}^{-1}\right)$ but were increased in prednisolone-treated mice $\left(53.4 \pm 5.1 \mathrm{mg} \mathrm{dL}^{-1}\right)$. In contrast, mice treated with $400 \mathrm{mg} \mathrm{kg}^{-1}$ per dose of ACE had decreased urine creatinine (34\% lower) compared to the SLE-disease group. Compared to creatinine in the blood, ACE maintained the glomerular function of kidneys in clearance of creatinine.

3.3. ACE Modestly Decreases the Production of Serum AntidsDNA Antibodies. In SLE, the levels of serum anti-dsDNA increase with the progression of SLE. As shown in Figure 2, the levels of anti-dsDNA IgG in vehicle-treated NZB/W F1 mice were dramatically elevated to $145.8 \pm 46.4 \mathrm{mg} \mathrm{dL}^{-1}$ at the end of the 12 week period compared to the reference normal C57BL/6j mice $\left(1.72 \pm 0.05 \mathrm{mg} \mathrm{dL}^{-1}\right)$, suggesting that SLE was successfully established. Unexpectedly, the levels of anti-dsDNA IgG were not inhibited by prednisolone $\left(144.5 \pm 95.8 \mathrm{mg} \mathrm{dL}^{-1}\right)$ but the levels of anti-dsDNA IgG were reduced to $79.6 \pm 18.7 \mathrm{mg} \mathrm{dL}^{-1}$ (45\% inhibition) and to $123.9 \pm 27.6 \mathrm{mg} \mathrm{dL}^{-1}$ (15\% inhibition) in NZB/W F1 mice treated with 100 and $200 \mathrm{mg} \mathrm{kg}^{-1}$ per dose of ACE, respectively. Treatment of mice with $100 \mathrm{mg} \mathrm{kg}^{-1}$ per dose of ACE reduced the production of auto-antibodies, suggesting that the suppression of the immune response might be one of the pharmaceutical actions of ACE.

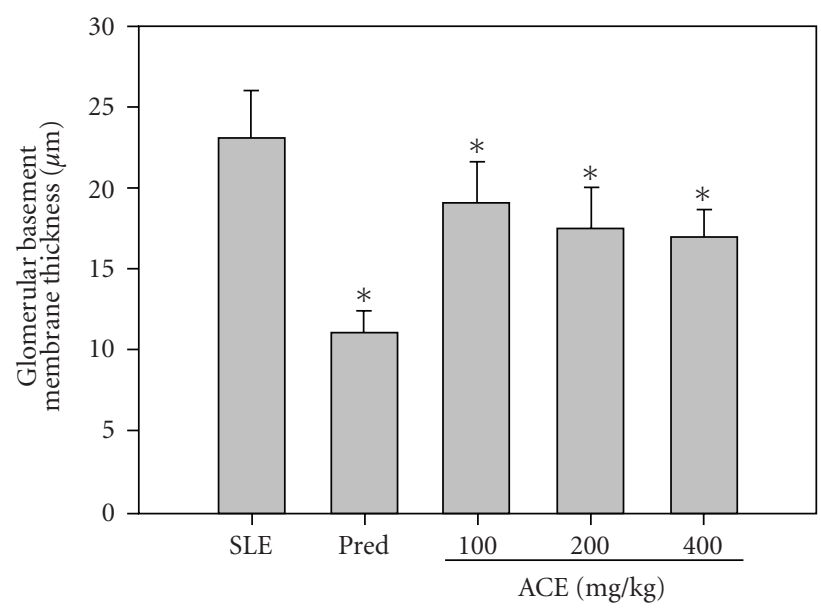

FIGURE 3: ACE inhibits glomerular basement membrane thickening in SLE-prone mice. The NZB/W F1 mice were treated with different dosages of $\operatorname{ACE}\left(100,200\right.$ and $\left.400 \mathrm{mg} \mathrm{kg}^{-1}\right)$ and prednisolone $\left(1.25 \mathrm{mg} \mathrm{kg}^{-1}\right)$ consecutively for 5 days per week for 12 weeks. At the end of experiment, kidney was excised after sacrifice of animals and subject to pathological examination. The thickness of kidney glomerular basement membrane was determined by staining with PAS. The thickness was measured using a microscope.

3.4. ACE Treatment Protects Kidneys via Inhibition of Glomerular Basement Membrane Thickening. Because death among SLE patients typically results from nephritis, we examined the capillary walls of the kidney glomeruli by staining with PAS. As shown in Figure 3, prednisolone suppressed thickening of the glomeruli basement membrane to $11 \pm 1.32 \mu \mathrm{m}$ in SLE-prone mice, whereas the thickness of the glomeruli basement membrane was $23 \pm 2.98 \mu \mathrm{m}$ in vehicle-treated mice. Thickening of the kidney glomeruli basement membrane was also significantly suppressed by ACE treatment in a dose-dependent manner (thickness $=19.1 \pm 2.6 \mu \mathrm{m}, 17.5 \pm 2.6 \mu \mathrm{m}$ and $17 \pm 1.7 \mu \mathrm{m}$ for mice treated with 100, 200 and $400 \mathrm{mg} \mathrm{kg}^{-1}$ per dose of ACE, respectively. Although ACE treatment only moderately inhibited thickening of glomerular basement membrane, it did protect the kidney glomeruli from immunological damage. These results suggested that ACE treatment attenuated the onset of nephritis, thereby reducing the risk of death.

3.5. Anti-Inflammation of Antroquinonol. To understand the possible mechanism of ACE action, antroquinonol, the major component of ACE, was investigated for antiinflammatory activity. RAW 264.7 cells were treated with antroquinonol at $0.256,2.56,25.6$ and $256 \mu \mathrm{M}$. Antroquinonol inhibited the production of TNF- $\alpha$ and IL- $1 \beta$ in LPS-induced inflammation in a dose-dependent manner (Figures 4(a) and 4(b)). In particular, a dose of $256 \mu \mathrm{M}$ antroquinonol inhibited LPS-induced TNF- $\alpha$ and IL- $1 \beta$ secretion by 75 and $78 \%$, respectively. This result showed that antroquinonol might exert anti-inflammation activities in ACE-treated SLE-prone mice. 


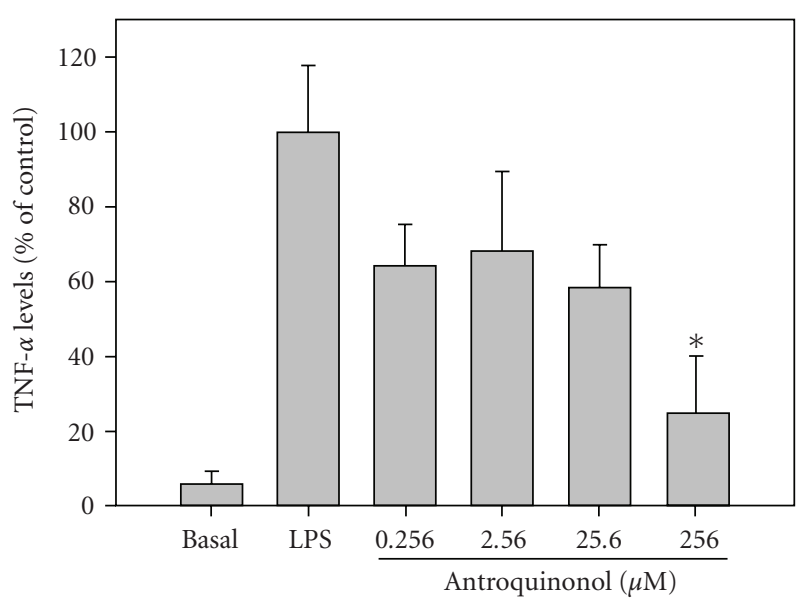

(a)

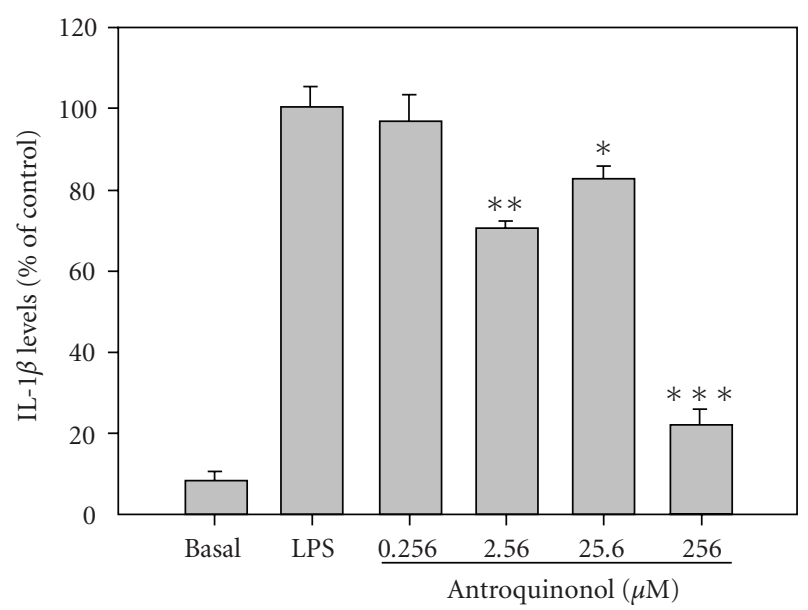

(b)

FIGURE 4: Antroquinonol inhibits cytokine secretion in LPS-treated RAW 264.7 cells. The Raw 264.7 cells were treated with different concentrations of antroquinonol in the presence of LPS for 24 hours. The conditioned medium was subject to the determination of (a) TNF- $\alpha$ and (b) IL- $1 \beta$ levels. Data point of experiment was performed in triplicate and normalized by the induction of LPS as percentage. ${ }^{*} P<.05,{ }^{* *} P<.01,{ }^{* * *} P<.001$ versus LPS control, significant difference tested using student's $t$-test.

\section{Discussion}

Nephritis in SLE patients is the major cause of death due to auto-immune destruction of the kidneys. Elevated urine protein and BUN are also observed among patients with nephritis [16]. In this study, an extract of a camphorata, a herbal medicine used in Taiwan, maintained normal growth among SLE-prone mice and protected the kidneys from immunological damage, allowing for normal kidney function with respect to clearance of BUN and creatinine. Additionally, the thickening of the kidney glomerular basement membrane was suppressed, suggesting that ACE attenuated the progression of nephritis in SLE-prone mice. Taken together, these results demonstrate that ACE protects kidney function in SLE-prone animals via an unknown mechanism, suggesting that ACE may have efficacy for treatment of SLE.
Pro-inflammatory cytokines play a central role in acute and chronic liver inflammation. Among these proinflammatory cytokines, TNF- $\alpha$ and IL- $1 \beta$ are involved in the etiology of several diseases $[17,18]$. Therefore, inhibition of pro-inflammatory cytokines is a strategy for prevention of immunological damage to organs [19]. Brennan et al. [20] have also reported enhanced renal expression of TNF- $\alpha$ and IL- $1 \beta$ in a SLE-prone murine model and that either TNF- $\alpha$ or IL- $1 \beta$ accelerated renal injury. Thus, it has been suggested that targeting the pro-inflammatory cytokines, such as TNF$\alpha$ and IL- $1 \beta$, is a desirable strategy for treatment of human SLE [21]. In this study, antroquinonol, the major active component of ACE, inhibited the production of TNF- $\alpha$ and IL- $1 \beta$ in LPS-induced RAW 264.7 cells, suggesting that this anti-inflammatory activity may contribute to the function of ACE in attenuation of the progression of lupus nephritis.

In conclusion, ACE reduced urine protein and creatinine levels and caused a reduction in the kidney glomerular basement membrane thickness, suggesting that ACE is able to protect the kidneys from the immunological damage characteristic of this autoimmune disease.

\section{Funding}

Golden Biotechnology Corp., Taiwan.

\section{Acknowledgments}

We are grateful to Mr Tsai CL (Chinese Herbal Medicine Program, Development Center for Biotechnology, Taiwan) for his technical assistance in histopathological microsection.

\section{References}

[1] L. Morel, C. Mohan, Y. Yu et al., "Multiplex inheritance of component phenotypes in a murine model of lupus," Mammalian Genome, vol. 10, no. 2, pp. 176-181, 1999.

[2] P. E. Lipsky, "Systemic lupus erythematosus: an autoimmune disease of B cell hyperactivity," Nature Immunology, vol. 2, no. 9, pp. 764-766, 2001.

[3] L. D. Heinlen, M. T. McClain, J. Merrill et al., "Clinical criteria for systemic lupus erythematosus precede diagnosis, and associated autoantibodies are present before clinical symptoms," Arthritis and Rheumatism, vol. 56, no. 7, pp. 23442351, 2007.

[4] P. J. Mosca, H. K. Lyerly, T. M. Clay, M. A. Morse, and H. K. Lyerly, "Dendritic cell vaccines," Frontiers in Bioscience, vol. 12, pp. 4050-4060, 2007.

[5] M. K. Elliott, T. Jarmi, P. Ruiz, Y. Xu, V. M. Holers, and G. S. Gilkeson, "Effects of complement factor D deficiency on the renal disease of MRL/lpr mice," Kidney International, vol. 65, no. 1, pp. 129-138, 2004.

[6] H. Jyonouchi, P. W. Kincade, and R. A. Good, "Agedependent changes in B lymphocyte lineage cell populations of autoimmune-prone BXSB mice," Journal of Immunology, vol. 134, no. 2, pp. 858-864, 1985.

[7] B. D. Greenstein, "Lupus: why women?" Journal of Women's Health and Gender-Based Medicine, vol. 10, no. 3, pp. 233-239, 2001. 
[8] L. Ozmen, D. Roman, M. Fountoulakis, G. Schmid, B. Ryffel, and G. Garotta, "Experimental therapy of systemic lupus erythematosus: the treatment of $\mathrm{NZB} / \mathrm{W}$ mice with mouse soluble interferon- $\gamma$ receptor inhibits the onset of glomerulonephritis," European Journal of Immunology, vol. 25, no. 1, pp. 6-12, 1995.

[9] T.-H. Lee, C.-K. Lee, W.-L. Tsou, S.-Y. Liu, M.-T. Kuo, and W.-C. Wen, "A new cytotoxic agent from solid-state fermented mycelium of Antrodia camphorata," Planta Medica, vol. 73, no. 13, pp. 1412-1415, 2007.

[10] Y.-C. Shen, Y.-H. Wang, Y.-C. Chou et al., "Evaluation of the anti-inflammatory activity of zhankuic acids isolated from the fruiting bodies of Antrodia camphorata," Planta Medica, vol. 70, no. 4, pp. 310-314, 2004.

[11] Y. Y. Wu, C. C. Chen, C. C. Chyau, S. Y. Chung, and Y. W. Liu, "Modulation of inflammation-related genes of polysaccharides fractionated from mycelia of medicinal basidiomycete Antrodia camphorata," Acta Pharmacologica Sinica, vol. 28, pp. 258-267, 2007.

[12] G.-J. Wang, H.-W. Tseng, C.-J. Chou, T.-H. Tsai, C.-T. Chen, and M.-K. Lu, "The vasorelaxation of Antrodia camphorata mycelia: involvement of endothelial $\mathrm{Ca}(2+)-\mathrm{NO}-\mathrm{cGMP}$ pathway," Life Sciences, vol. 73, no. 21, pp. 2769-2783, 2003.

[13] T.-Y. Song, S.-L. Hsu, and G.-C. Yen, "Induction of apoptosis in human hepatoma cells by mycelia of Antrodia camphorata in submerged culture," Journal of Ethnopharmacology, vol. 100, no. 1-2, pp. 158-167, 2005.

[14] Y.-L. Hsu, Y.-C. Kuo, P.-L. Kuo, L.-T. Ng, Y.-H. Kuo, and C.C. Lin, "Apoptotic effects of extract from Antrodia camphorata fruiting bodies in human hepatocellular carcinoma cell lines," Cancer Letters, vol. 221, no. 1, pp. 77-89, 2005.

[15] J.-M. Chang, C.-M. Cheng, L.-M. Hung, Y.-S. Chung, and R.Y. Wu, "Potential use of Plectranthus amboinicus in the treatment of rheumatoid arthritis," Evidence-Based Complementary and Alternative Medicine, vol. 7, no. 1, pp. 115-120, 2010.

[16] S. T. Nezhad and R. Sepaskhah, "Correlation of clinical and pathological findings in patients with lupus nephritis: a fiveyear experience in Iran," Saudi Journal of Kidney Diseases and Transplantation, vol. 19, no. 1, pp. 32-40, 2008.

[17] A. M. Wolf, D. Wolf, H. Rumpold et al., "The kinase inhibitor imatinib mesylate inhibits TNF- $\alpha$ production in vitro and prevents TNF-dependent acute hepatic inflammation," Proceedings of the National Academy of Sciences of the United States of America, vol. 102, no. 38, pp. 13622-13627, 2005.

[18] G. Ramadori, J. van Damme, H. Rieder, and K.-H. Meyer zum Buschenfelde, "Interleukin 6, the third mediator of acutephase reaction, modulates hepatic protein synthesis in human and mouse. Comparison with interleukin $1 \beta$ and tumor necrosis factor- $\alpha$, European Journal of Immunology, vol. 18, no. 8, pp. 1259-1264, 1988.

[19] H. Tilg and C. P. Day, "Management strategies in alcoholic liver disease," Nature Clinical Practice Gastroenterology and Hepatology, vol. 4, no. 1, pp. 24-34, 2007.

[20] D. C. Brennan, M. A. Yui, R. P. Wuthrich, and V. E. Kelley, "Tumor necrosis factor and IL-1 in New Zealand Black/White mice. Enhanced gene expression and acceleration of renal injury," Journal of Immunology, vol. 143, pp. 3470-3475, 1989.

[21] S. Lemay, C. Mao, and A. K. Singh, "Cytokine gene expression in the MRL/lpr model of lupus nephritis," Kidney International, vol. 50, no. 1, pp. 85-93, 1996. 


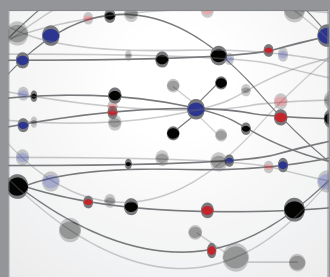

The Scientific World Journal
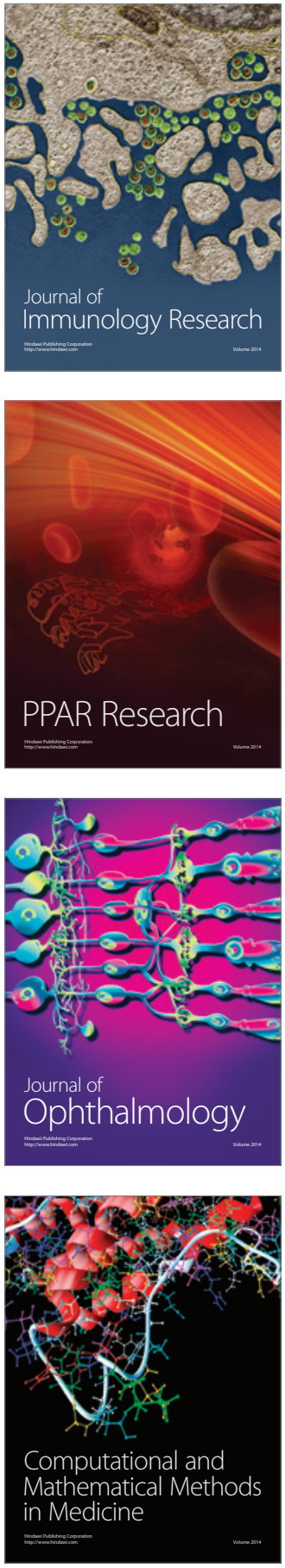

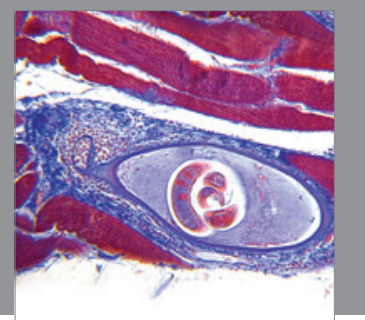

Gastroenterology

Research and Practice
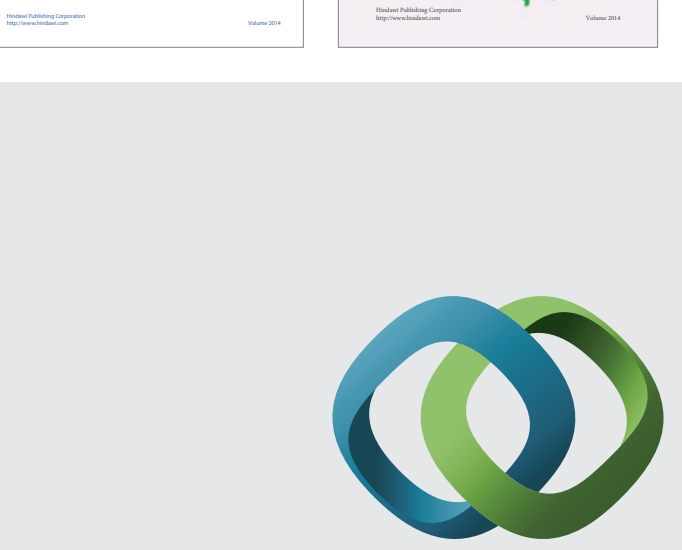

\section{Hindawi}

Submit your manuscripts at

http://www.hindawi.com
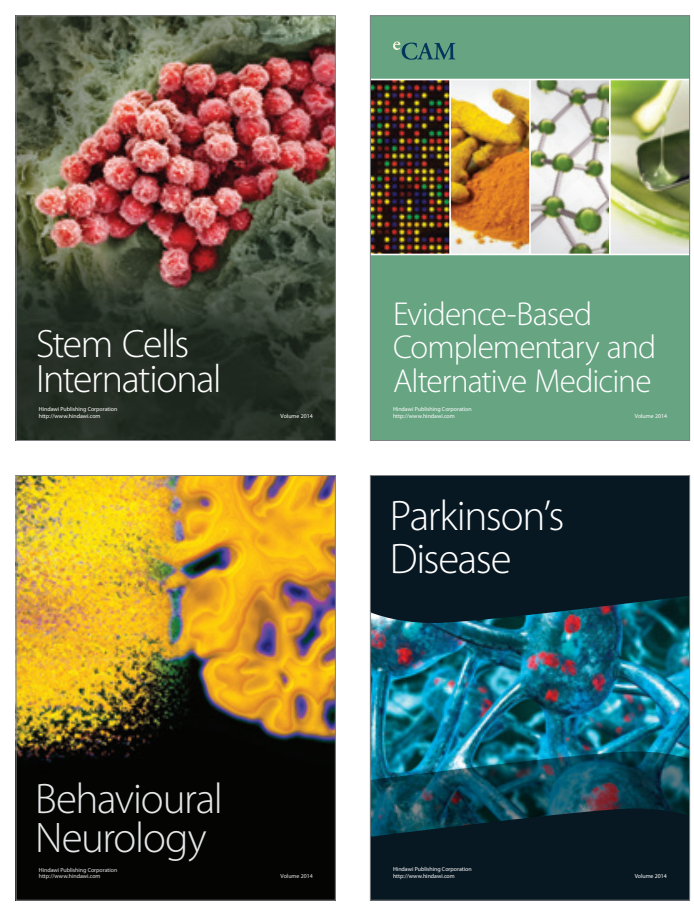

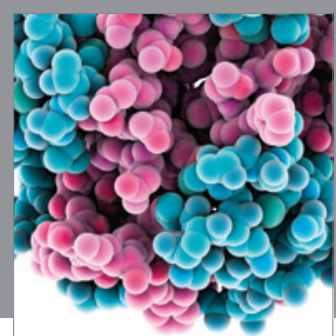

Journal of
Diabetes Research

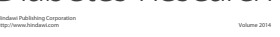

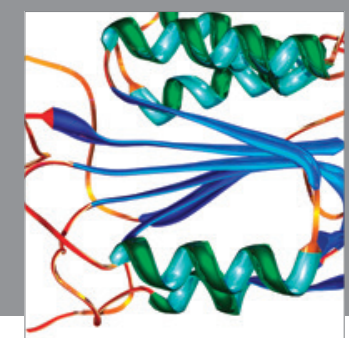

Disease Markers
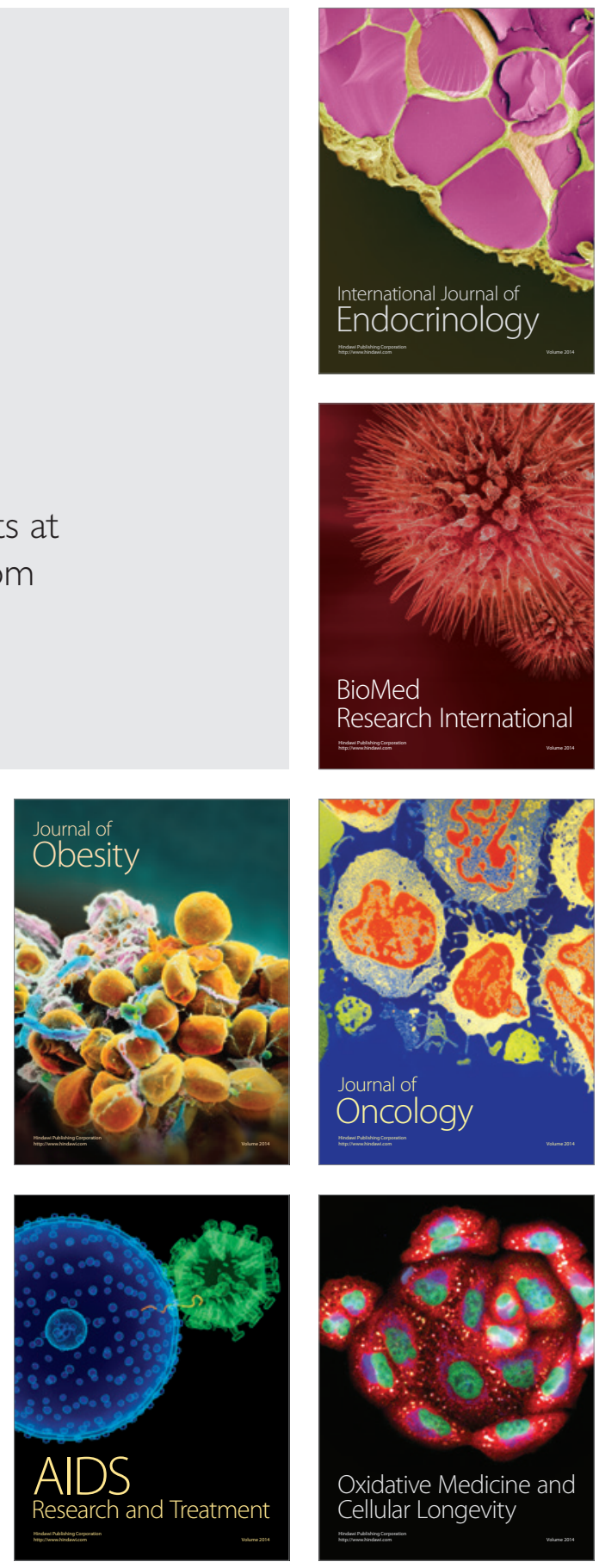